\title{
BMJ Open Cross-sectional assessment of tuberculosis and HIV prevalence in 13 correctional facilities in Zambia
}

\author{
Mary Kagujje (D) , ${ }^{1}$ Paul Somwe, ${ }^{2}$ Sisa Hatwiinda, ${ }^{1}$ Joel Bwalya, ${ }^{2}$ Tamala Zgambo, ${ }^{3}$ \\ Moomba Thornicroft, ${ }^{1}$ Fiammetta Maria Bozzani, ${ }^{4}$ Clement Moonga, ${ }^{1}$ \\ Monde Muyoyeta ${ }^{1}$
}

To cite: Kagujje M, Somwe P, Hatwiinda S, et al. Crosssectional assessment of tuberculosis and HIV prevalence in 13 correctional facilities in Zambia. BMJ Open 2021:11:e052221. doi:10.1136/ bmjopen-2021-052221

- Prepublication history and additional supplemental material for this paper are available online. To view these files, please visit the journal online (http://dx.doi.org/10.1136/ bmjopen-2021-052221).

Received 14 April 2021 Accepted 14 September 2021

Check for updates

(C) Author(s) (or their employer(s)) 2021. Re-use permitted under CC BY-NC. No commercial re-use. See rights and permissions. Published by BMJ.

${ }^{1}$ Tuberculosis Department, Centre for Infectious Disease Research in Zambia, Lusaka, Zambia

${ }^{2}$ Strategic Information Department, Centre for Infectious Disease Research in

Zambia, Lusaka, Zambia

${ }^{3}$ Health directorate, Zambia

Correctional Service, Lusaka,

Zambia

${ }^{4}$ Faculty of Public Health and Policy, London School of Hygiene \& Tropical Medicine, London, UK

Correspondence to

Dr Mary Kagujje;

mkagujje@gmail.com

\section{ABSTRACT}

Objective To determine the prevalence of tuberculosis

(TB) and HIV in 13 Zambian correctional facilities.

Methods Cross-sectional study.

Setting 13 correctional facilities in seven of the 10 provinces in Zambia.

Participants All incarcerated individuals were eligible for TB and HIV screening and testing. Of the total study population of 9695 individuals, which represent $46.2 \%$ of total correctional population at the beginning of the study, 8267 and 8160 were screened for TB and HIV, respectively. Interventions TB and HIV screening and testing was done between July 2018 and February 2019.

Primary outcome measures All forms of TB, bacteriologically confirmed TB, drug-resistant TB, HIV. Results Prevalence of all forms of TB and bacteriologically confirmed TB was 1599 (1340-1894) per 100000 population and 1056 (847-1301) per 100000 population, respectively. Among those with bacteriologically confirmed TB, 4.6\% (1.3\%-11.4\%) had drug-resistant TB.

There was no statistically significant difference in the prevalence of all forms of TB, bacteriologically confirmed TB and drug resistant TB between adults and juveniles: $(p=0.82),(p=0.23),(p=0.68)$ respectively. Of the bacteriologically confirmed TB cases, $28.7 \%$ were asymptomatic. The prevalence of HIV was $14.3 \%$ (13.6\%$15.1 \%)$. The prevalence of HIV among females was 1.8 times the prevalence of HIV among males $(p=0.01)$. Conclusion Compared with the study in 2011 which screened inmates representing $30 \%$ of the country's inmate population, then the prevalence of all forms of TB and HIV in correctional facilities has reduced by about $75 \%$ and $37.6 \%$, respectively. However, compared with the general population, the prevalence of all forms of TB and HIV was 3.5 and 1.3 times higher, respectively. TB/ HIV programmes in correctional facilities need further strengthening to include aspects of juvenile-specific TB programming and gender responsive HIV programming.

\section{INTRODUCTION}

Globally, correctional facilities are disproportionately affected by tuberculosis (TB) and the HIV. ${ }^{1-3}$ In some correctional facilities, the prevalence of TB has been reported to be up to 100 times higher than the prevalence in the general population ${ }^{1}$ while the prevalence
Strengths and limitations of this study

- This is the only study on prevalence of tuberculosis (TB) and HIV in Zambian correctional facilities in the past 8 years.

- Results are generalisable to the 13 correctional facilities as a large sample was screened for TB and HIV.

Data disaggregates can inform targeted interventions to reduce the burden of both diseases.

- Variations in TB screening algorithms could have underestimated TB prevalence.

Asymptomatic TB was not consistently screened for.

of HIV has been reported to be up to 23 times higher than the prevalence in the general population. ${ }^{3}$ The poor living conditions in correctional facilities perpetuate TB and HIV. While overcrowding, poor ventilation, HIV, poor nutrition and late case detection perpetuate $\mathrm{TB}$, sexual violence, sharing of sharp objects and lack of access to condoms perpetuate HIV. ${ }^{45}$ Additionally, incarcerated people often come from socioeconomically disadvantaged backgrounds where the burden of TB and HIV is already high. ${ }^{13}$

In 2011, the prevalence of all forms of TB in six Zambian correctional facilities representing $30 \%$ of the total incarcerated population was 6428 per 100000 population, which was 18 times higher than the national estimates. ${ }^{6}$ In the same study, $0.6 \%$ of those with bacteriologically confirmed $\mathrm{TB}$ had rifampicin-resistant TB and the overall prevalence of HIV was $22.9 \%$, which was 1.5 times the national prevalence.

Since the last documented prevalence survey, several interventions including test and treat for HIV, health systems strengthening, nutritional support, TB and HIV entry screening, among others, have been put in place to control the burden of $\mathrm{TB}$ 
and its associated risk factors in Zambia correctional facilities. ${ }^{7-10}$

This study aimed to determine the current prevalence of all forms of TB, bacteriologically confirmed TB and drug-resistant (DR) TB, and the prevalence of HIV in 13 Zambian correctional facilities.

\section{METHODS}

\section{Study design}

We present an analysis of cross-sectional data collected under programmatic conditions by the Elton John Juvenile Offenders' Health (EJJOH) project. The EJJOH project was a health system strengthening project aimed at supporting provision of holistic and integrated health services to juvenile offenders. While the project primarily targeted juveniles, its support was extended to adults being held in the same facility with the juveniles so as to improve infectious disease control. The project screened the incarcerated population as part of its baseline assessment.

\section{Study setting and population}

Zambia has 87 correctional facilities with a total capacity of 9150 incarcerated individuals. ${ }^{11}$ However, the total incarcerated population in Zambia was slightly over 21000 in 2018 and 22823 in 2019. In 2019, almost one in five individuals detained were in pretrial detention. ${ }^{11}$ The data were collected between July 2018 and February 2019 in 13 correctional facilities with a combined population of 9695 , representing $46.2 \%$ of the total correctional facility population in Zambia in 2018. The 13 correctional facilities had been purposefully selected by the EJJOH project because they held a significant number of juveniles. The facilities include Lusaka Central, Kamwala Remand, Livingstone Central, Katombora Reformatory School, Nakambala Approved School, Mukobeko Medium, Ndola Remand, Kamfinsa State, Chingola, Insakwe Approved School, Chipata Central, Mongu Central and Kasama Central (locations shown in online supplemental figure $1)$. The reformatory and approved schools hold ordered (convicted) juveniles (persons less than 19 years old) ${ }^{12}$; the other facilities are intended only for adults and circumstantial children ${ }^{13}$ but also hold juveniles who are still undergoing trial.

Across Zambia, routinely incarcerated people should undergo universal TB screening and HIV testing at entry or within 7 days of admission into correctional facilities. However, in some facilities, entry screening is not done due to various constraints. Depending on availability of logistics, periodic TB and HIV mass screening is carried out, with freedom to opt out of HIV testing but not TB screening and testing. TB screening is mandatory to increase early $\mathrm{TB}$ detection and treatment so as to protect other inmates from TB.

\section{Study procedures}

A project-specific register was used; it was a modification of the National Presumptive TB Register with additional data elements on entry point, category of individual and history of TB. All inmates were screened for TB; those who did not opt out were tested for HIV. The screening point was documented under one of the following categories: mass screening, entry screening from the community or entry screening transfer from other correctional facility. The categories of individuals included adults and juveniles. Those already on anti-TB treatment at the time of screening were documented as $\mathrm{TB}$ cases and those on antiretroviral therapy (ART) were recorded as HIV positive and were not retested. Those with cough, fever, weight loss, nightsweats, chest pain and shortness of breath, irrespective of duration, were considered patients with presumptive $\mathrm{TB}$ and submitted sputum for testing using GeneXpert (Xpert MTB/Rif Assay; Cepheid, Sunnyvale, California, USA). Symptomatic individuals with a negative GeneXpert were referred for chest X-ray (CXR) depending on the clinician's discretion. There were three variations to this algorithm: (1) in Lusaka Central, a random proportion of the incarcerated population received CXR in addition to symptoms screening and those with either abnormal CXR or symptoms submitted sputum for GeneXpert; (2) at Ndola Remand, all except those already on TB treatment submitted sputum irrespective of symptoms; and (3) in Kabwe Medium, fluorescent microscopy (FM) was used for sputum examination instead of GeneXpert.

Alere Determine HIV-1/2 test (AlereHIV-1/2; Abbott, Chicago, Illinois, USA) was used for HIV screening and SD Bioline HIV-1/2 (SD Bioline HIV-1/2; Abbott) for confirmation of positive screening test, following the standard Zambian HIV testing algorithm. All individuals received pretest and post-test HIV counselling. HIV-positive inmates were commenced on ART within 1-2 days.

\section{Data analysis}

STATA Statistical Software V.14 (StataCorp, College Station, Texas, USA) was used for data analysis. A descriptive analysis was done to determine the characteristics of the population screened and the prevalence of TB and HIV; overall prevalence and prevalence among subgroups were determined. The prevalence of all forms of TB included bacteriologically confirmed TB and clinically diagnosed TB. Bacteriologically confirmed TB prevalence included those who had a positive GeneXpert or FM result, while patients already on TB treatment at time of screening were excluded from this analysis since data on the type of TB had not been collected. DR TB prevalence included incarcerated people with rifampicin resistance on GeneXpert. Missing data were excluded from the analysis.

Additionally, a $\chi^{2}$ test was done to determine if there was a statistically significant difference in prevalence of TB and HIV between residents and new entrants into correctional facilities. New entrants were defined as incarcerated people whose entry point was entry screening from community while residents were defined as those whose 


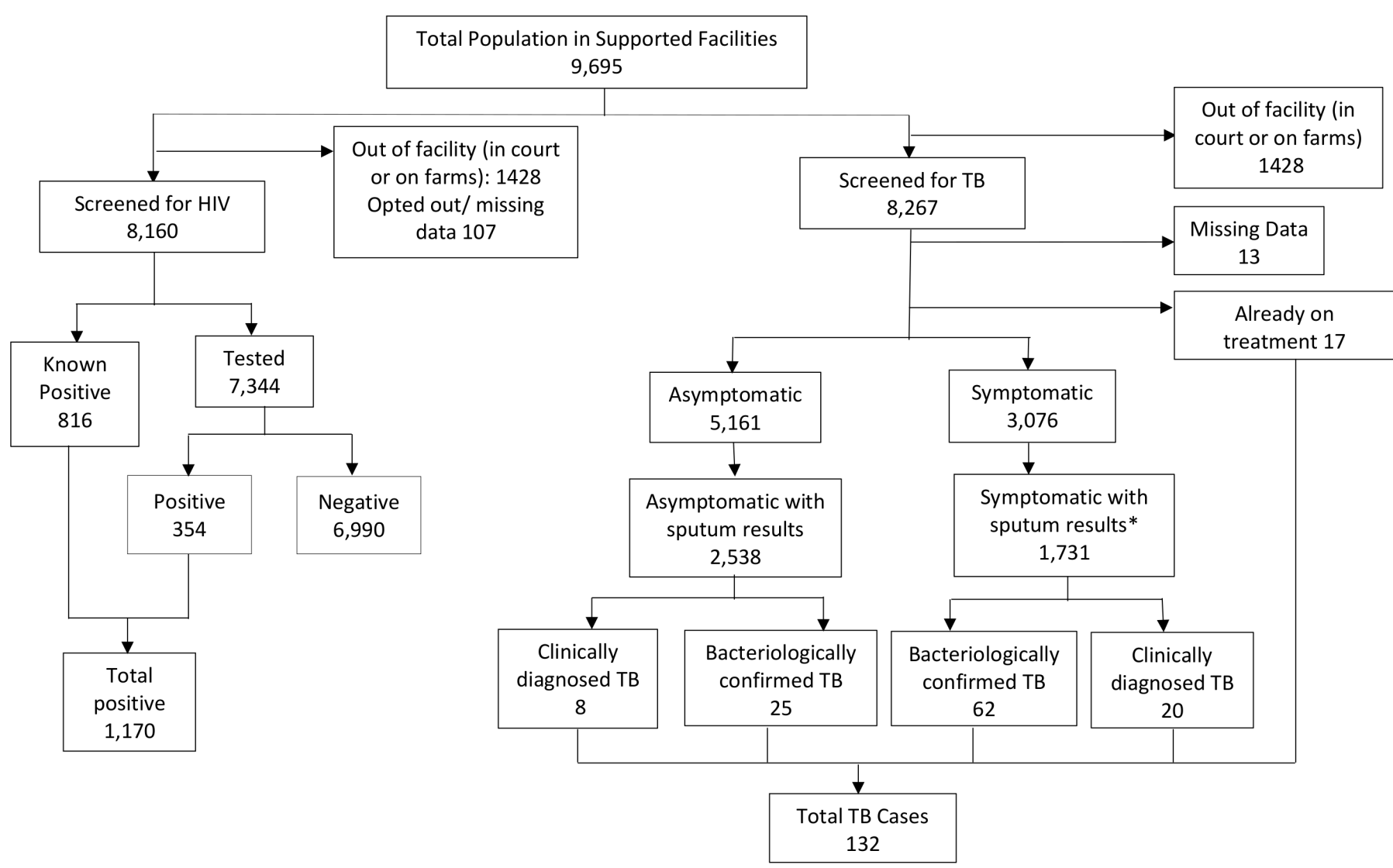

Figure 1 Flow diagram of tuberculosis (TB) screening and diagnosis. *All symptomatic patients submitted sputum; however, some correctional facilities only documented results of patients with positive results.

entry point was either mass screening or entry screening transfer from other correctional facility.

\section{Patient and public involvement}

The development of the research questions was intended to inform priority setting by the EJJOH project based on the disease burden in correctional facilities. The incarcerated population were not involved in the design of the project. The correctional health committees constituting of the incarcerated persons, correctional officers and healthcare workers were involved in the data collection. A representative of the correctional health committee at each correctional facility participated in the dissemination meeting on project findings.

\section{RESULTS}

\section{Flow diagram and participant characteristics}

Of the total adult and juvenile population of 9695 in the 13 correctional facilities, $8160(84.2 \%)$ were screened for HIV and 8267 (85.3\%) were screened for TB (figure 1). Individuals not screened were $1428(14.7 \%)$ and they constituted those either in court or the farms. Of those screened for HIV, 1170 (14.3\%) were HIV positive, of which 816 were known positive and 354 were new positives, while $6990(85.7 \%)$ were HIV negative. Of those screened for TB, $17(0.2 \%)$ were already on treatment, $3076(37.3 \%)$ individuals had symptoms of TB, 5161
(62.5\%) were asymptomatic while $13(0.2 \%)$ had missing data. A total of 4269 individuals had documented sputum results. Eighty-seven bacteriologically confirmed TB cases were reported including $25(28.7 \%)$ asymptomatic individuals and $62(71.3 \%)$ symptomatic individuals. A total of 132 TB cases were identified including $87(65.9 \%)$ bacteriologically confirmed TB cases, 28 (21.2\%) clinically diagnosed TB cases and the $17(12.9 \%)$ that were already on TB treatment at the time of screening.

Of those screened, $7805(94.41 \%)$ were adults and 462 $(5.58 \%)$ were juveniles (table 1$)$. The overall median age (IQR) of the participants was 32 years (IQR 10-93); the median ages for the adults and juveniles were 33 (IQR 19-93) and 17 (IQR 10-18), respectively. The males were $8167(98.79 \%)$, participants with a history of TB were 467 (5.65\%), resident inmates were $7767(93.95 \%)$ while new entrants were $497(6.01 \%)$.

\section{Prevalence of all forms of TB and bacteriologically confirmed TB}

The overall prevalence of all forms of TB was 1598 (13391892) per 100000 population while the overall prevalence of bacteriologically confirmed TB was 1056 (844-1301) per 100000 population (table 2). There was no statistically significant difference in the prevalence of both all forms of TB and bacteriologically confirmed TB between males and females, $(\mathrm{p}=0.51)$ and $(\mathrm{p}=1.00)$, respectively. It was 


\begin{tabular}{lc}
\hline $\begin{array}{l}\text { Table } 1 \\
\text { Variable }\end{array}$ & Participants $(\mathbf{n}=\mathbf{8 2 6 7})$ \\
\hline $\begin{array}{l}\text { Category of individual, } \mathrm{n}(\%) \\
\text { Adults }\end{array}$ & $7805(94.41)$ \\
\hline Juveniles & $462(5.58)$ \\
\hline Median age (IQR) & \\
\hline Overall & $32(10-93)$ \\
\hline Adults ( $\geq 19$ years) & $33(19-93)$ \\
\hline Juveniles (<19 years) & $17(10-18)$ \\
\hline Sex, $\mathrm{n}(\%)$ & \\
\hline Male & $8167(98.79)$ \\
\hline Female & $89(1.08)$ \\
\hline Missing & $11(0.13)$ \\
\hline History of TB, $\mathrm{n}(\%)$ & \\
\hline Yes & $467(5.65)$ \\
\hline No & $7786(94.18)$ \\
\hline Missing & $14(0.17)$ \\
\hline Type of screening visit, $\mathrm{n}(\%)$ & \\
\hline Mass screening & $7602(91.92)$ \\
\hline Entry screening other correctional facility & $165(2.00)$ \\
\hline Entry screening community & $497(6.01)$ \\
\hline Missing & $3(0.04)$ \\
\hline
\end{tabular}

TB, tuberculosis.

the same for adults and juveniles, $(\mathrm{p}=0.82)$ and $(\mathrm{p}=0.23)$, respectively, and the new entrants and residents, $(\mathrm{p}=0.25)$ and $(\mathrm{p}=0.21)$, respectively.

\section{Prevalence of DR TB}

Among the bacteriologically confirmed TB cases, the overall prevalence of DR TB was 4.6\% (1.3\%-11.4\%) (table 3 ). There was no statistically significant difference in prevalence of DR TB between males and females $(p=0.95)$, between adults and juveniles $(p=0.68)$, between those with and those without history of TB $(\mathrm{p}=0.72)$ and between the new entrants and residents $(\mathrm{p}=0.26)$.

\section{Prevalence of HIV}

The overall HIV prevalence was $14.3 \%$ (13.6\%-15.1\%) (table 4). The prevalence of HIV among males was $14.1 \%$ (13.4\%-14.9\%) and among females $25.8 \%$ (16.6\%$35.1 \%)(\mathrm{p}=0.01)$. The prevalence of HIV among adults and juveniles was $15.0 \%(14.1 \%-15.7 \%)$ and $3.9 \%$ $(2.3 \%-6.2 \%)(p<0.01)$, respectively. There was no statistically significant difference in prevalence of HIV between residents and new entrants $(\mathrm{p}=0.05)$.

\section{DISCUSSION \\ Statement of principal findings}

This study found that in Zambian correctional facilities, the prevalence of all forms of $\mathrm{TB}$, bacteriologically confirmed TB and DR TB was 3.5 times higher, ${ }^{14} 1.7$ times higher ${ }^{14}$ and 3.5 times higher, ${ }^{15}$ respectively, than the respective prevalence in the general population. Additionally, the overall prevalence of HIV was 1.3 times higher than the prevalence in the general population, ${ }^{16}$ and the prevalence of HIV among females was 1.8 times higher than the prevalence of HIV among males within

Table 2 Prevalence of all forms of TB and bacteriologically confirmed TB

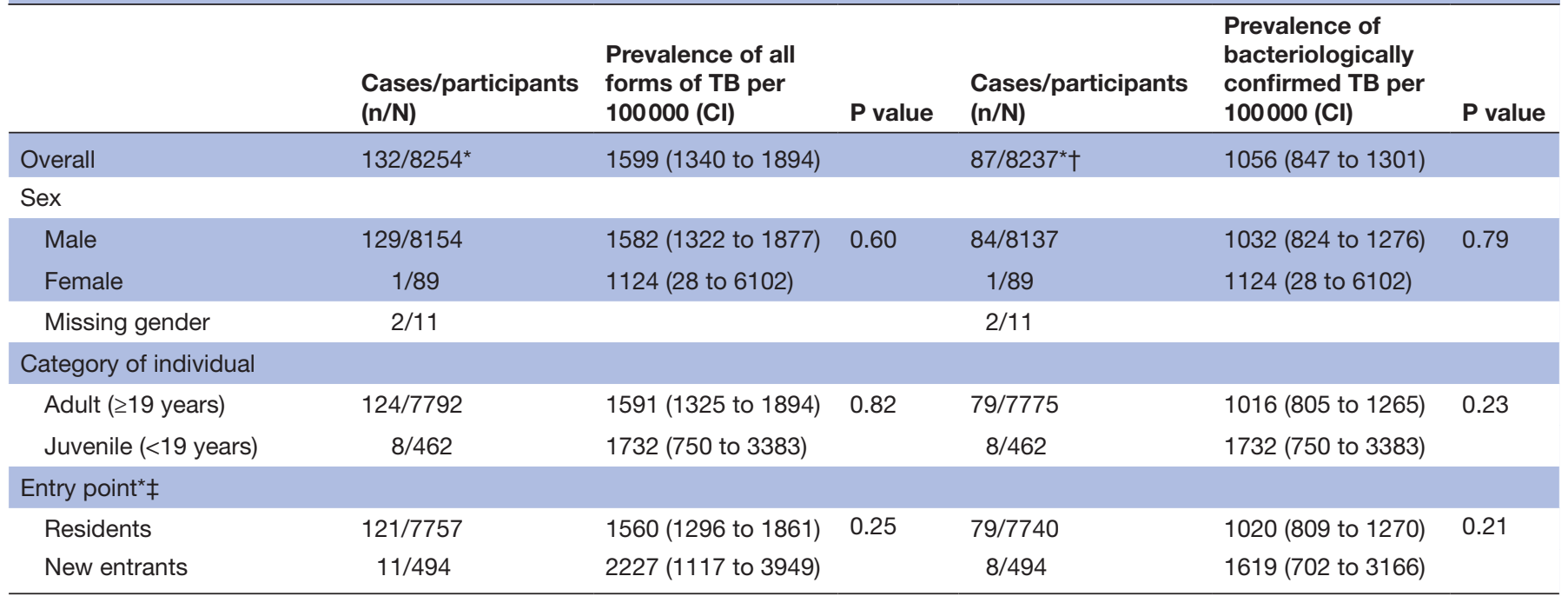

Residents include those screened through mass screening and those under entry screening as a transfer from other correctional facility. New entrants include those screened under entry screening from the community (police cells).

*Thirteen participants had missing values on TB.

†Seventeen participants were already on TB treatment, bacteriological status unknown.

$\ddagger$ Three participants had missing values on entry point.

TB, tuberculosis. 


\begin{tabular}{|c|c|c|c|}
\hline & $\begin{array}{l}\text { Cases/ } \\
\text { participants } \\
(\mathrm{n} / \mathrm{N})\end{array}$ & $\begin{array}{l}\text { Prevalence of DR } \\
\text { TB \% (CI) }\end{array}$ & $P$ value \\
\hline Overall & $4 / 87$ & $4.6(1.3$ to 11.4$)$ & \\
\hline \multicolumn{4}{|l|}{ Sex } \\
\hline Male & $4 / 84$ & 4.8 (1.3 to 11.7$)$ & 0.95 \\
\hline Female & $0 / 1$ & $0(0 \text { to } 97.5)^{*}$ & \\
\hline Missing & $0 / 2$ & & \\
\hline \multicolumn{4}{|c|}{ Category of individual } \\
\hline $\begin{array}{l}\text { Adults } \\
\text { ( } \geq 19 \text { years) }\end{array}$ & $4 / 79$ & 5.1 (1.4 to 12.5$)$ & 0.68 \\
\hline $\begin{array}{l}\text { Juveniles } \\
\text { (<19 years) }\end{array}$ & $0 / 8$ & $0(0 \text { to } 3.7)^{*}$ & \\
\hline \multicolumn{4}{|l|}{ History of TB } \\
\hline No & $3 / 64$ & 4.7 (1.0 to 13.1$)$ & 0.72 \\
\hline Yes & $1 / 23$ & 4.3 (0.1 to 21.9) & \\
\hline \multicolumn{4}{|l|}{ Entry point } \\
\hline Residents & $3 / 76$ & 3.8 (0.8 to 10.7) & 0.26 \\
\hline $\begin{array}{l}\text { New } \\
\text { entrants }\end{array}$ & $1 / 8$ & 12.5 (0.3 to 52.7$)$ & \\
\hline
\end{tabular}

Residents include those screened through mass screening and those under entry screening as a transfer from other correctional facility. New incarcerated individuals include those screened under entry screening from the community (police cells).

*One sided, $97.5 \% \mathrm{Cl}$.

DR TB, drug-resistant tuberculosis.

correctional facilities. Of the bacteriologically confirmed TB cases, $28.7 \%$ were asymptomatic.

\section{Study findings in relation to other studies}

It is noteworthy that there is no statistically significant difference in prevalence of all forms of TB and bacteriologically confirmed TB between juveniles and adults and that in fact the point estimates for TB in juveniles were higher; generally older adults have a higher TB burden than adolescents. ${ }^{17} 18$ This suggests that the disproportionate access to TB services and health services in general among juveniles in Zambian correctional facilities reported between 2009 and 2010 has persisted. ${ }^{19}$ Another significant contrast relative to the general population is the absence of a statistically significant difference in prevalence of bacteriologically confirmed TB between males and females. ${ }^{14}$ This could be due to absence of gender-related differences in exposure to risk factors for TB infection and disease but could also be due to the small sample size and very wide CIs among females.

In comparison to the 2010-2011 study, the prevalence of all forms of TB has reduced by about $75 \%$ while the prevalence of bacteriologically confirmed TB has reduced by $50 \%{ }^{6}$ The reduction in prevalence of all forms of TB

\begin{tabular}{|c|c|c|c|}
\hline & $\begin{array}{l}\text { Cases/ } \\
\text { participants } \\
(\mathrm{n} / \mathrm{N})\end{array}$ & $\begin{array}{l}\text { Prevalence of HIV } \\
\% \text { (Cl) }\end{array}$ & P value \\
\hline Overall & $1170 / 8160 *$ & 14.3 (13.6 to 15.1$)$ & \\
\hline \multicolumn{4}{|l|}{ Sex } \\
\hline Male & $1139 / 8061$ & 14.1 (13.4 to 14.9$)$ & 0.00 \\
\hline Female & $23 / 89$ & 25.8 (17.4 to 36.2 ) & \\
\hline $\begin{array}{l}\text { Missing } \\
\text { sex }\end{array}$ & $8 / 10$ & & \\
\hline \multicolumn{4}{|c|}{ Category of individual } \\
\hline $\begin{array}{l}\text { Adults } \\
\text { ( } \geq 19 \text { years) }\end{array}$ & $1153 / 7727$ & 15.0 (14.1 to 15.7$)$ & 0.00 \\
\hline $\begin{array}{l}\text { Juveniles } \\
\text { ( }<19 \text { years) }\end{array}$ & $17 / 433$ & 3.9 (2.3 to 6.2 ) & \\
\hline \multicolumn{4}{|l|}{ Entry point* $†$} \\
\hline Residents & $1118 / 7699$ & 14.5 (13.7 to 15.3$)$ & 0.06 \\
\hline $\begin{array}{l}\text { New } \\
\text { entrants }\end{array}$ & $52 / 460$ & 11.3 (8.6 to 14.6$)$ & \\
\hline
\end{tabular}

Residents include those screened through mass screening and those under entry screening as a transfer from other correctional facility. New incarcerated individuals include those screened under entry screening from the community (police cells).

*One hundred and seven participants either opted out of HIV testing or had missing data.

†Three ${ }^{3}$ participants had missing entry point, 2 of which also had missing HIV status.

and bacteriologically confirmed TB could be a result of the TB interventions being implemented within the Zambian correctional facilities since 2011. This explanation is supported by findings from an observational and modelling study done in Brazil: entry screening, active screening for TB among inmates, TB preventive therapy and annual mass screening independently reduce the incidence of TB in correctional facilities by $10.3 \%$, $35 \%, 23.5 \%$ and $47.5 \%$, respectively, after a period of 10 years and a combination of these interventions reduces the TB incidence by $79.2 \%$ after a period of 10 years. ${ }^{20}$ However, it is worth mentioning that though the previous study used a more sensitive algorithm involving X-ray and culture ${ }^{21} 22$ for all inmates, the reduction is so large that it cannot simply be explained by use of different algorithms. Other countries in sub-Saharan Africa with results involving multiple correctional facilities report TB prevalence ranging from 457 to 888 per 100000 population. ${ }^{23-25}$ However, a direct comparison to the prevalence reported in the other countries can not be done due to differences in definitions of TB used and differences in prevalence in the general population.

The prevalence of DR TB among people with no history of TB is similar to the prevalence among people with history of $\mathrm{TB}$, suggesting significant transmission of DR TB either in correctional facilities or in the 
communities where the incarcerated people come from, or both. Strengthening TB infection control can reduce transmission of DR TB. ${ }^{26}$ In comparison to the 2010-2011 study, the prevalence of DR TB has increased by $667 \%{ }^{6}$ The increasing trend of DR TB in the Zambian correctional facility setting is also seen at the global and national levels. ${ }^{27}$ The prevalence of DR TB in this study can not be directly compared with other correctional facility settings since the forms of drug resistance reported are different. ${ }^{28-30}$

Similar to the national picture, the prevalence of HIV was higher among adults than juveniles and was higher among females than males. ${ }^{16}$ However, the prevalence of HIV in women relative to the prevalence of HIV in men is much higher in the incarcerated population than the general population because women with HIV risk factors like sex worker status, intimate partner violence and drug and substance abuse are over-represented in this population. ${ }^{31}$ Additionally, women are exposed to sexual abuse while in custody and they have more access barriers to HIV prevention, testing and treatment services compared with men. ${ }^{32}$ Despite the very high rates of HIV in this group, relative to the study done by Simooya $e t$ al in 1999, which showed a prevalence of $33 \%$ in females, the prevalence of HIV has reduced. ${ }^{33}$ There has been a $37.6 \%$ reduction in overall prevalence of HIV since the study in 2010-2011. ${ }^{6}$ The reduction in prevalence of HIV in correctional facilities is attributable to the reduction of HIV prevalence in the general population, ${ }^{16}$ the implementation of test and treat across Zambia, ${ }^{34}$ entry HIV testing and treatment ${ }^{6}$ and use of correctional health committees to strengthen $\mathrm{TB} /$ HIV service delivery at facility level. ${ }^{9}$ Among African countries with studies involving several correctional facilities, Zambia's prevalence is lower than South Africa's ${ }^{25}$ but higher than Burkina Faso and Uganda.

The difference in prevalence of TB and HIV between residents and new entrants into correctional facilities was not statistically significant. This is possibly due to the following reasons: (a) individuals entering correctional facilities come from socioeconomically disadvantaged backgrounds where prevalence of TB and HIV is already high ${ }^{1}$; (b) there are high rates of recidivism ${ }^{35}$; and (c) detainees spend long periods in police cells, which have similar conditions to the correctional facilities. ${ }^{36} 37$ However, the small sample size and wide CIs especially for the new entrants are a limiting factor for drawing any inferences from this comparison. This finding highlights the contribution of imported TB and HIV cases to the burden of disease in correctional facilities and underscores the importance of entry screening within this setting.

\section{Strengths and limitations}

This study provides the most recent evidence on prevalence of TB and HIV in Zambian correctional facilities. The results of this study are generalisable to the 13 correctional facilities, as a large sample representing $85 \%$ and $84 \%$ of the 13 correctional facility population was screened for TB and HIV, respectively. By virtue of the data being disaggregated, it provides an opportunity for targeting of interventions that can reduce the burden of both diseases. However, there were variations in the strength of screening algorithms for $\mathrm{TB}$, hence the prevalence of TB could have been underestimated in some correctional facilities. That said, among all forms of TB cases, it is possible that some of the clinically diagnosed TB cases might not be true TB cases as there are other differential causes of CXR abnormalities that mimic TB. Inmates in court or on the farms were not screened for TB which could have introduced bias during data collection. Additionally, asymptomatic TB was not consistently screened for.

\section{CONCLUSION}

Despite significant progress over the last decade in controlling TB and HIV in Zambian correctional facilities, these continue to be disproportionately affected by both diseases. TB/HIV programmes in correctional facilities need further strengthening to include aspects of juvenile-specific TB programming, gender responsive HIV programming and holistic integrated service delivery as TB and HIV are not exclusive health concerns of incarcerated individuals. Additionally, there is a need to consider use of more sensitive algorithms that include CXR to minimise the risk of missing asymptomatic TB cases. Additional studies are required to determine the true prevalence of asymptomatic TB in correctional facilities, to better understand the reason for high HIV burden among females in correctional facilities and to determine the prevalence of TB and HIV using a sample whose results can be generalised to all the correctional facilities in Zambia.

Acknowledgements The Zambia Correctional Service, the Ministry of Community Development and Social Welfare and the correctional health committees are acknowledged for the support provided to the EJJOH project team during data collection. Innocent Mwaba is acknowledged for drawing the map showing study sites.

Contributors Conceived and designed the study: MK, SH, CM, MM. Database design and data curation: PS, JB. Implemented the study: MK, SH, MT, TZ, CM, MM. Data analysis: PS, MK, FMB. Wrote the original draft: MK. Reviewed the manuscript: SH, MT, JB, PS, TZ, FMB, CM, MM. Approved the final version to be published: MK, $\mathrm{SH}, \mathrm{PS}, \mathrm{MT}, \mathrm{JB}, \mathrm{TZ}, \mathrm{FMB}, \mathrm{CM}, \mathrm{MM}$.

Funding This research was funded by the Elton John AIDS Foundation under the Elton John Juveniles Offenders' Health (EJJOH) project.

Map disclaimer The inclusion of any map (including the depiction of any boundaries therein), or of any geographic or locational reference, does not imply the expression of any opinion whatsoever on the part of BMJ concerning the legal status of any country, territory, jurisdiction or area or of its authorities. Any such expression remains solely that of the relevant source and is not endorsed by BMJ. Maps are provided without any warranty of any kind, either express or implied.

\section{Competing interests None declared.}

\section{Patient consent for publication Not applicable.}

Ethics approval Approval to use the programmatic data was obtained from the University of Zambia Biomedical Research Ethics Committee (No: 018-11-18) and the London School of Hygiene \& Tropical Medicine Ethics Committee (No: 21332). Since data were collected under programmatic conditions, no consent was sought for TB screening and verbal consent and assent were obtained for HIV testing. 
The EJJOH project had obtained permission from the Zambia Correctional Service and the Ministry of Community Development and Social Services to conduct the screening activities including testing of juveniles. When migrating data from the paper-based registers to the electronic database, participant-identifying information was excluded.

Provenance and peer review Not commissioned; externally peer reviewed.

Data availability statement Data are available upon reasonable request.

Supplemental material This content has been supplied by the author(s). It has not been vetted by BMJ Publishing Group Limited (BMJ) and may not have been peer-reviewed. Any opinions or recommendations discussed are solely those of the author(s) and are not endorsed by BMJ. BMJ disclaims all liability and responsibility arising from any reliance placed on the content. Where the content includes any translated material, BMJ does not warrant the accuracy and reliability of the translations (including but not limited to local regulations, clinical guidelines, terminology, drug names and drug dosages), and is not responsible for any error and/or omissions arising from translation and adaptation or otherwise.

Open access This is an open access article distributed in accordance with the Creative Commons Attribution Non Commercial (CC BY-NC 4.0) license, which permits others to distribute, remix, adapt, build upon this work non-commercially, and license their derivative works on different terms, provided the original work is properly cited, appropriate credit is given, any changes made indicated, and the use is non-commercial. See: http://creativecommons.org/licenses/by-nc/4.0/.

ORCID iD

Mary Kagujje http://orcid.org/0000-0003-4818-6548

\section{REFERENCES}

1 World Health Organization. Tuberculosis in prisons. Available: https:// www.who.int/tb/areas-of-work/population-groups/prisons-facts/en/ [Accessed 20 Jul 2020].

2 Telisinghe L, Charalambous S, Topp SM, et al. Hiv and tuberculosis in prisons in sub-Saharan Africa. Lancet 2016;388:1215-27.

3 Dolan K, Wirtz AL, Moazen B, et al. Global burden of HIV, viral hepatitis, and tuberculosis in prisoners and detainees. Lancet 2016;388:1089-102.

4 Reid SE, Topp SM, Turnbull ER, et al. Tuberculosis and HIV Control in Sub-Saharan African Prisons: "Thinking Outside the Prison Cell". J Infect Dis 2012;205:S265-73.

5 World Health Organization Regional Office for Europe. Prisons and health. Copenhagen, Denmark, 2014: 45-70.

6 Maggard KR, Hatwiinda S, Harris JB, et al. Screening for tuberculosis and testing for human immunodeficiency virus in Zambian prisons. Bull World Health Organ 2015;93:93-101.

7 Ubumi Prisons Iniative. Zambian prisons. Available: https://ubumi. net/zambian_prisons.html [Accessed 4 Aug 2020].

8 Herce ME, Hoffmann CJ, Fielding K, et al. Universal test-and-treat in Zambian and South African correctional facilities: a multisite prospective cohort study. Lancet HIV 2020;7:e807-16.

9 Topp SM, Sharma A, Moonga CN, et al. Evaluation of a health system strengthening initiative in the Zambian prison system. BMJ Glob Health 2018;3:e000614.

10 Herce ME, Muyoyeta M, Topp SM, et al. Coordinating the prevention, treatment, and care continuum for HIV-associated tuberculosis in prisons: a health systems strengthening approach. Curr Opin HIV AIDS 2018;13:492.

11 Institute of Crime and Justice Policy Research B. World prison brief 2020. Available: https://www.prisonstudies.org/country/zambia [Accessed 21 Jul 2020].

12 Government of the Republic of Zambia. The juvenile act. Chapter 53 of the laws of Zambia; 1964.

13 Government of the Republic of Zambia. The prisons act Lusaka, Zambia: government printer, 2004. Available: https://www.parliament. gov.zm/node/840 [Accessed 13 May 2020].

14 Kapata N, Chanda-Kapata P, Ngosa W, et al. The prevalence of tuberculosis in Zambia: results from the first national TB prevalence survey, 2013-2014. PLoS One 2016;11:e0146392.
15 Kapata N, Mbulo G, Cobelens F, et al. The Second Zambian National Tuberculosis Drug Resistance survey - a comparison of conventional and molecular methods. Trop Med Int Health 2015;20:1492-500.

16 Ministry of Health Zambia. Zambia population-based HIV impact assessment 2016. Lusaka, 2019.

17 Donald PR, Marais BJ, Barry CE. Age and the epidemiology and pathogenesis of tuberculosis. The Lancet 2010;375:1852-4.

18 Stop TB partnership. Tuberculosis situation in 2019, Zambia. Available: http://stoptb.org/resources/cd/ZMB_Dashboard.html [Accessed 19 Feb 2021].

19 Todrys KW, Amon JJ. Human rights and health among juvenile prisoners in Zambia. Int J Prison Health 2011;7:10-17.

20 Mabud TS, de Lourdes Delgado Alves M, Ko Al, et al. Evaluating strategies for control of tuberculosis in prisons and prevention of spillover into communities: an observational and modeling study from Brazil. PLoS Med 2019;16:e1002737.

21 World Health Organisation. Chest radiography in tuberculosis case detection. Switzerland, 2016. Available: https://apps.who. int/iris/bitstream/handle/10665/252424/9789241511506-eng.pdf; jsessionid $=72$ EC9D02021FEBF4C6CCA41896818F45? sequence $=1$ [Accessed 10 Jun 2021].

22 World Health Organisation. Who operational Handbook on TB diagnosis. Geneva, 2020. Available: https://www.who.int/ publications/i/item/who-operational-handbook-on-tuberculosismodule-3-diagnosis---rapid-diagnostics-for-tuberculosis-detection [Accessed 10 Jun 2021].

23 Melese A, Demelash $\mathrm{H}$. The prevalence of tuberculosis among prisoners in Ethiopia: a systematic review and meta-analysis of published studies. Arch Public Health 2017;75:1-9.

24 Banda HT, Gausi F, Harries AD, et al. Prevalence of smear-positive pulmonary tuberculosis among prisoners in Malawi: a national survey. Int J Tuberc Lung Dis 2009;13:1557-9.

25 Stevenson KA, Podewils LJ, Zishiri VK, et al. Hiv prevalence and the cascade of care in five South African correctional facilities. PLoS One 2020;15:e0235178.

26 Organization WH. Who policy on TB infection control in healthcare facilities, congregate settings and households. World Health Organization, 2009.

27 World health Organisation. Global tuberculosis report 2019, 2019. Available: https://apps.who.int/iris/bitstream/handle/10665/329368/ 9789241565714-eng.pdf?ua=1

28 Gizachew Beza M, Hunegnaw E, Tiruneh M. Prevalence and associated factors of tuberculosis in prisons settings of East Gojjam zone, Northwest Ethiopia. Int J Bacteriol 2017;2017:1-7.

29 Séri B, Koffi A, Danel C, et al. Prevalence of pulmonary tuberculosis among prison inmates: a cross-sectional survey at the correctional and detention facility of Abidjan, Côte d'Ivoire. PLoS One 2017;12:e0181995.

30 Noeske J, Ndi N, Mbondi S. Controlling tuberculosis in prisons against confinement conditions: a lost case? experience from Cameroon. Int J Tuberc Lung Dis 2011;15:223-7.

31 United Nations Office on Drug and Crime U. Women and HIV in prison settings Austria, 2008. Available: https://www.unodc.org/ documents/middleeastandnorthafrica/drug-prevention-healthpublications/WOMEN_AND_HIV_IN_PRISON_SETTINGS.pdf [Accessed 1 Feb 2021].

32 Todrys KW, Amon JJ. Health and human rights of women imprisoned in Zambia. BMC Int Health Hum Rights 2011;11:1-7.

33 Simooya OO, Sanjobo NE, Kaetano L, et al. 'Behind walls': a study of HIV risk behaviours and seroprevalence in prisons in Zambia. AIDS 2001;15:1741-4.

$34 \mathrm{MoH}$ Z. Zambia consolidated guidelines on treatment and prevention of HIV infection. Lusaka, 2016.

35 Yukhnenko D, Sridhar S, Fazel S. A systematic review of criminal recidivism rates worldwide: 3-year update. Wellcome Open Res 2019;4:28.

36 Henostroza G, Topp SM, Hatwiinda S, et al. The high burden of tuberculosis (TB) and human immunodeficiency virus (HIV) in a large Zambian prison: a public health alert. PLoS One 2013;8:e67338.

37 Todrys KW, Amon JJ, Malembeka G, et al. Imprisoned and imperiled: access to HIV and TB prevention and treatment, and denial of human rights, in Zambian prisons. J Int AIDS Soc 2011;14:8-11. 